\title{
ANALISIS KADAR TIMBAL (Pb), SENG (Zn) DAN TEMBAGA (Cu) PADA IKAN BANDENG (Chanos chanos Forsk.) YANG BERASAL DARI LABBAKKANG KAB. PANGKEP SECARA SPEKTROFOTOMETRI SERAPAN ATOM (SSA)
}

\author{
Azizah Zulfiah $^{1}$, Seniwati $^{2}$, Sukmawati $^{1}$ \\ 1 Fakultas Farmasi Universitas Muslim Indonesia, Makassar \\ ${ }^{2}$ Fakultas Matematika dan IImu Pengetahuan Alam Universitas Hasanuddin, \\ Makassar \\ Email : azizahzulfiah@gmail.com
}

\begin{abstract}
The research was done to analysis of amount lead $(\mathrm{Pb})$, zinc $(\mathrm{Zn})$ and copper (Cu) at milkfish (Chanos chanos Forsk.) from Labbakkang Pangkep by Atomic Absorbtion Spectrophotometry (AAS). Before to be analised, first to do destruction of milkfish (Chanos chanos Forsk.) later on $\mathrm{HNO}_{3}$. Quantitative analysis used atomic absorbtion spectrophotometry (AAS) at wave length of 283,3 $\mathrm{nm}$ for lead (Pb), 213,9 $\mathrm{nm}$ for zinc $(\mathrm{Zn})$ and 324,8 $\mathrm{nm}$ for copper (Cu). Result of research find average rates of lead (Pb) and copper (Cu) from Labbakkang Pangkep is 0,0392 mg/kg and 0,0882 $\mathrm{mg} / \mathrm{kg}$. From result of research to showing that average rates $\mathrm{Pb}$ and $\mathrm{Cu}$ in the location, it is not over from still limit and according to Dirjen POM regulation.
\end{abstract}

Keywords : Analysis of amount, lead (Pb), zinc ( $\mathrm{Zn})$, copper ( $\mathrm{Cu})$, milkfish, atomic absorbtion spectrophotometry (AAS).

\section{PENDAHULUAN}

Labbakkang adalah salah satu daerah yang terletak di Kabupaten Pangkep, dimana penduduknya banyak berprofesi sebagai petani tambak. Masyarakat setempat kebanyakan memelihara ikan bandeng. Ikan bandeng adalah salah satu jenis ikan yang sangat digemari oleh masyarakat, oleh karena itu perlu diteliti apakah ikan bandeng yang dibudidayakan aman untuk dikonsumsi. Makanan merupakan salah satu kebutuhan utama yang diperlukan oleh manusia selain air dan oksigen. Oleh karena itu, manusia selalu berusaha agar makanan yang dikonsumsinya aman. ${ }^{1}$ Salah satu zat makanan yang dibutuhkan oleh tubuh kita untuk mengganti sel-sel yang rusak dan membantu pertumbuhan adalah protein. Ikan merupakan salah satu jenis makanan yang mengandung protein hewani yang relatif murah dan mudah didapat.

Pada umumnya makanan masyarakat Indonesia cenderung masih lebih banyak mengandung 
Analisis kadar timbal $(\mathrm{Pb})$, seng $(\mathrm{Zn})$ dan tembaga $(\mathrm{Cu})$ pada ikan bandeng (Chanos chanos Forsk.) yang berasal dari Labbakkang Kab. Pangkep secara Spektrofotometri Serapan Atom

karbohidrat dari pada protein. Untuk menanggulangi

permasalahan

tersebut,

pemerintah

telah

mencanangkan program perbaikan kualitas makanan rakyat melalui instruksi Presiden RI No.14, pada tahun 1974, yaitu mengadakan perbaikan menu makanan rakyat dengan cara meningkatkan keanekaragaman jenis makanan maupun jumlahnya. Namun kenyataannya belum dilaksanakan sepenuhnya di masyarakat, sehingga masih ditemukan kelompok gizi buruk. $^{2}$

Untuk memenuhi kebutuhan akan ikan, maka dikembangkan pembudidayaan ikan kolam, baik di kolam darat (perairan air tawar, air payau) maupun di kolam pantai (perairan laut). ${ }^{3}$ Faktor penting dalam penentuan kualitas ikan hasil budi daya adalah air dan lingkungannya. Pada sektor perikanan, pencemaran kemungkinan terjadi pada ikan-ikan yang hidup di perairan pantai atau kolam budi daya di sekitar permukiman penduduk yang disebabkan oleh air sungai yang telah tercemar oleh rangkaian irigasi yang melewati sawah, limbah industri, dan limbah rumah tangga ${ }^{1}$, sehingga tidak menjamin air yang dipakai untuk mengisi kolam budi daya yang letaknya jauh dari perindustrian dapat terbebas dari pencemaran. ${ }^{4}$

Selain pencemaran air, pencemaran udara juga turut menyumbang logam berat, khususnya logam timbal. Contoh kasusnya adalah persawahan berada di dekat jalan raya padat menghasilkan beras dengan kandungan logam timbal yang tinggi. ${ }^{5}$

Timbal adalah logam toksik yang berbahaya karena dapat menimbulkan penghambatan pembentukan sel-sel darah merah dan mempengaruhi anggota tubuh lain. Gejala keracunan timbal yang sering timbul adalah mual, muntah dengan muntahan menyerupai susu karena $\mathrm{Pb}$ klorida, dan sakit perut hebat. Pb yang diserap dengan cepat dapat menyebabkan sindrom syok yang juga disebabkan oleh kehilangan cairan lewat saluran cerna. Dapat timbul kerusakan ginjal, dan kematian dapat terjadi dalam 1-2 hari. ${ }^{6}$

Seng (Zn) adalah komponen alam yang terdapat di kerak bumi. Zn adalah logam yang memiliki karakteristik cukup reaktif, berwarna putih-kebiruan, pudar bila terkena uap udara, dan terbakar bila terkena udara dengan api hijau terang. Logam Zn sebenarnya tidak toksik, tetapi dalam keadaan sebagai ion, $\mathrm{Zn}$ bebas memiliki toksisitas tinggi. ${ }^{7}$ 
Analisis kadar timbal $(\mathrm{Pb})$, seng $(\mathrm{Zn})$ dan tembaga $(\mathrm{Cu})$ pada ikan bandeng (Chanos chanos Forsk.) yang berasal dari Labbakkang Kab. Pangkep secara Spektrofotometri Serapan Atom

Kelebihan $\mathrm{Zn}$ hingga dua sampai tiga kali AKG menurunkan absorpsi tembaga. Kelebihan sampai sepuluh kali AKG mempengaruhi metabolisme kolesterol, mengubah nilai lipoprotein, dan tampaknya dapat mempercepat timbulnya kejadian aterosklerosis. Dosis konsumsi seng (Zn) sebanyak $2 \mathrm{gr}$ atau lebih dapat menyebabkan muntah, diare, demam, kelelahan yang sangat, anemia, dan gangguan reproduksi. Suplemen seng $(\mathrm{Zn})$ bisa menyebabkan keracunan, begitupun makanan yang asam dan disimpan dalam kaleng yang dilapisi seng $(\mathrm{Zn}){ }^{8}$

\section{Tembaga (Cu) merupakan} mineral mikro karena keberadaannya dalam tubuh sangat sedikit namun diperlukan dalam proses fisiologis. Walaupun dibutuhkan tubuh dalam jumlah sedikit, bila kelebihan dapat mengganggu kesehatan atau mengakibatkan keracunan. ${ }^{9}$

\section{Berdasarkan}

Peraturan

Pemerintah Republik Indonesia Nomor 82 Tahun 2001 kadar maksimum yang diizinkan untuk logam $\mathrm{Zn}$ adalah 0,05 $\mathrm{mg} / \mathrm{l}$; logam $\mathrm{Pb}$ adalah 0,03 mg/l; logam Cr (valensi 6) adalah 0,05 mg/l, dan untuk logam $\mathrm{Cu}$ adalah 0,02 $\mathrm{mg} / \mathrm{l}^{10}$ Sedangkan berdasarkan Keputusan Direktur Jenderal Pengawasan Obat dan Makanan
Nomor 03725/B/SK/VII/89 kadar maksimum yang diizinkan untuk logam $\mathrm{Pb}$ adalah 2,0 mg/kg; logam $\mathrm{Zn}$ adalah 100,0 mg/kg; dan untuk logam Cu adalah $20,0 \mathrm{mg} / \mathrm{kg}^{11}$

\section{METODE PENELITIAN}

\section{Alat dan bahan penelitian}

Alat-alat yang digunakan pada penelitian ini adalah Batang pengaduk, Blender, Cawan porselin, Corong, Gelas piala (Pyrex), Gelas ukur (Pyrex), Hot plate, Kertas saring Whatman, Labu erlemeyer (Pyrex), Labu tentukur (Pyrex), Neraca analitik (Kern 770), Oven (Gallenkamp), Pipet tetes, Pipet volume (Brand), Spektrofotometer serapan atom (Varian ASC 7000), Tabung reaksi, Tanur listrik (Furnace). Adapun bahanbahan yang digunakan pada penelitian ini adalah, Air suling/aquadest, Asam nitrat $\left(\mathrm{HNO}_{3}\right)$ (p.a Merck), sampel Ikan Bandeng (Chanos chanos Forsk.)

\section{Prosedur Penelitian}

\section{Pengambilan Sampel}

Pengambilan sampel ikan bandeng (Chanos chanos Forsk.) dilakukan secara acak didaerah Labbakkang Kab.Pangkep.

\section{Pengolahan Sampel}

Sampel ikan bandeng dibersihkan dari sisik-sisiknya, lalu isi perut beserta insangnya dikeluarkan, kemudian dicuci dengan air sampai 
Analisis kadar timbal $(\mathrm{Pb})$, seng $(\mathrm{Zn})$ dan tembaga $(\mathrm{Cu})$ pada ikan bandeng (Chanos chanos Forsk.) yang berasal dari Labbakkang Kab. Pangkep secara Spektrofotometri Serapan Atom

bersih. Daging ikan yang telah dibersihkan kemudian dipisahkan dari tulangnya.

\section{Proses Destruksi}

Sampel daging ikan segar dihaluskan dengan menggunakan blender, lalu ditimbang sebanyak 25 gr, dimasukkan dalam kurs porselin yang telah konstan beratnya lalu diarangkan sampai kering, kemudian didestruksi dalam tanur pada suhu $500^{\circ} \mathrm{C}$ selama 4 jam sehingga menjadi abu. Setelah dingin ditambahkan $2 \mathrm{~mL}$ larutan $\mathrm{HNO}_{3}$ dan dipanaskan diatas hot plate. Diencerkan dengan aquadest hingga $50 \mathrm{~mL}$. Larutan ini digunakan untuk pemeriksaan keberadaan logam dan kadarnya dalam daging ikan yang dianalisis.

\section{Analisis Kuantitatif}

\section{Pembuatan Kurva Kalibrasi}

Larutan baku Pb 100 ppm: Larutan standar dipipet $10 \mathrm{~mL}$ dan dimasukkan kedalam labu ukur $100 \mathrm{~mL}$, ditambahkan larutan $\mathrm{HNO}_{3} \mathrm{P}$ sebanyak $2 \mathrm{~mL}$ hingga tepat garis tanda. Dari larutan tersebut dipipet 0,2; 0,$4 ; 0,6 ; 0,8$ dan $1,0 \mathrm{ml}$, dimasukkan ke dalam labu ukur $100 \mathrm{~mL}$, ditambahkan larutan $\mathrm{HNO}_{3} \quad \mathrm{P}$ sebanyak $2 \mathrm{~mL}$ sampai garis tanda. Larutan ini mengandung 0,$2 ; 0,4 ; 0,6$; 0,8 dan 1,0 ppm Pb.
Larutan baku Zn 100 ppm: Larutan standar dipipet $10 \mathrm{~mL}$ dan dimasukkan kedalam labu ukur $100 \mathrm{~mL}$, ditambahkan larutan $\mathrm{HNO}_{3} \mathrm{P}$ sebanyak $2 \mathrm{~mL}$ hingga tepat garis tanda. Dari larutan tersebut dipipet 0,2; 0,$4 ; 0,6 ; 0,8$ dan $1,0 \mathrm{~mL}$, dimasukkan ke dalam labu ukur $100 \mathrm{~mL}$, ditambahkan larutan $\mathrm{HNO}_{3} \quad \mathrm{P}$ sebanyak $2 \mathrm{~mL}$ sampai garis tanda. Larutan ini mengandung 0,$2 ; 0,4 ; 0,6$; 0,8 dan 1,0 ppm Zn.

Larutan baku Cu 100 ppm: Larutan standar dipipet $10 \mathrm{~mL}$ dan dimasukkan kedalam labu ukur $100 \mathrm{~mL}$, ditambahkan larutan $\mathrm{HNO}_{3} \quad \mathrm{P}$ sebanyak $2 \mathrm{~mL}$ hingga tepat garis tanda. Dari larutan tersebut dipipet 0,1 ; 0,2; 0,3; 0,4; dan 0,5 mL, dimasukkan ke dalam labu ukur $100 \mathrm{~mL}$, ditambahkan larutan $\mathrm{HNO}_{3} \mathrm{P} 2 \mathrm{~mL}$ sampai garis tanda. Larutan ini mengandung 0,$1 ; 0,2 ; 0,3 ; 0,4 ;$ dan 0,5 ppm Cu.

\section{Analisis Logam dalam Sampel}

Larutan sampel Ikan Bandeng hasil destruksi diukur absorbansinya dengan menggunakan

Spektrofotometer Serapan Atom. Absorban logam $\mathrm{Pb}$ diukur pada panjang gelombang 283,3 $\mathrm{nm}$, absorban logam $\mathrm{Cu}$ diukur pada panjang gelombang $324,8 \mathrm{~nm}$ dan untuk logam Zn, larutan sampel Ikan 
Analisis kadar timbal $(\mathrm{Pb})$, seng $(\mathrm{Zn})$ dan tembaga $(\mathrm{Cu})$ pada ikan bandeng (Chanos chanos Forsk.) yang berasal dari Labbakkang Kab. Pangkep secara Spektrofotometri Serapan Atom

Bandeng hasil destruksi dipipet $10 \mathrm{~mL}$ dimasukkan ke labu tentukur $50 \mathrm{~mL}$, dicukupkan sampai garis tanda dengan air suling kemudian diukur absorbansinya pada panjang gelombang $213,9 \mathrm{~nm}$.

\section{HASIL PENELITIAN}

Tabel 1. Hasil Identifikasi Kuantitatif Logam Timbal (Pb) pada Sampel Ikan Bandeng (Chanos chanos Forsk.)

\begin{tabular}{|c|c|c|c|c|c|}
\hline Rep & $\begin{array}{l}\text { Berat sampel } \\
\quad(\mathrm{mg})\end{array}$ & Absorban & $\begin{array}{c}\text { Konsentrasi } \\
(\mathrm{ppm})\end{array}$ & $\begin{array}{l}\text { Kadar } \\
(\mathrm{mg} / \mathrm{kg})\end{array}$ & $\begin{array}{c}\text { Rata-rata } \\
(\mathrm{mg} / \mathrm{kg})\end{array}$ \\
\hline 1 & 25.001 & $-0,0004$ & 0,0367 & 0 & \\
\hline II & 25.001 & 0,0001 & 0,0589 & 0,1176 & 0,0392 \\
\hline III & 25.001 & $-0,0002$ & 0,0467 & 0 & \\
\hline
\end{tabular}

Tabel 2. Hasil Analisis Kuantitatif Logam Tembaga (Cu) Pada Sampel Ikan Bandeng (Chanos chanos Forsk.)

\begin{tabular}{cccccc}
\hline A & $\begin{array}{c}\text { Berat sampel } \\
(\mathbf{m g})\end{array}$ & Absorban & $\begin{array}{c}\text { Konsentrasi } \\
(\mathbf{p p m})\end{array}$ & $\begin{array}{c}\text { Kadar } \\
(\mathbf{m g} / \mathbf{k g})\end{array}$ & $\begin{array}{c}\text { Rata-rata } \\
(\mathbf{m g} / \mathbf{k g})\end{array}$ \\
\hline I & 25.001 & 0,0216 & 0,1075 & 0,2149 & \\
II & 25.001 & 0,0230 & 0,1143 & 0,0228 & 0,0882 \\
III & 25.001 & 0,0272 & 0,1346 & 0,0026 & \\
\hline
\end{tabular}

\section{PEMBAHASAN}

Penelitian ini dilakukan dengan menganalisis kadar logam timbal $(\mathrm{Pb})$, seng $(\mathrm{Zn})$ dan tembaga $(\mathrm{Cu})$ pada ikan bandeng (Chanos chanos Forsk.) yang berasal dari Labbakkang Kabupaten Pangkep secara spektrofotometri serapan atom (SSA). Penelitian ini bertujuan menentukan kadar logam $\mathrm{Pb}, \mathrm{Zn}$ dan $\mathrm{Cu}$ pada ikan bandeng (Chanos chanos Forsk.).

Pada analisis kuantitatif digunakan alat spektrofotometer serapan atom karena alat ini memiliki kepekaan dan selektifitas yang tinggi dibandingkan dengan alat instrument yang lain dan alat ini juga sangat peka untuk analisis logam dalam kadar kecil (kurang dari 1 ppm).

Dari hasil penelitian kuantitatif menunjukkan bahwa kadar rata-rata logam $\mathrm{Pb}$ pada sampel ikan bandeng (Chanos chanos Forsk.) sebesar 0,0392 $\mathrm{mg} / \mathrm{kg}$, dan kadar rata-rata logam $\mathrm{Cu}$ sebesar 0,0882 $\mathrm{mg} / \mathrm{kg}$. Sedangkan untuk logam Zn, tidak terdapat pada sampel (tidak terdeteksi oleh alat), seperti yang terlihat pada 
Analisis kadar timbal $(\mathrm{Pb})$, seng $(\mathrm{Zn})$ dan tembaga $(\mathrm{Cu})$ pada ikan bandeng (Chanos chanos Forsk.) yang berasal dari Labbakkang Kab. Pangkep secara Spektrofotometri Serapan Atom

Tabel 1 dan 2. Keberadaan logam $\mathrm{Pb}$ dan persenyawaannya dalam badan perairan secara alamiah sebagai dampak dari aktivitas manusia. Secara alamiah, $\mathrm{Pb}$ dapat masuk ke badan perairan melalui pengkristalan $\mathrm{Pb}$ di udara dengan bantuan air hujan. Disamping itu, proses korosifikasi dari batuan mineral akibat hempasan gelombang dan angin juga merupakan salah satu jalur sumber $\mathrm{Pb}$ yang akan masuk ke dalam badan perairan. ${ }^{12}$ Untuk logam tembaga di alam dapat ditemukan dalam bentuk logam bebas, akan tetapi lebih banyak ditemukan dalam bentuk persenyawaan atau senyawa padat dalam bentuk mineral.Tembaga masuk keperairan merupakan faktor alamiah seperti terjadinya pengikisan dari batuan mineral sehingga terdapat debu, partikel-partikel tembaga yang terdapat dalam lapisan udara akan terbawa oleh hujan. Tembaga juga berasal dari buangan bahan yang mengandung tembaga seperti dari industri galangan kapal, industri pengolahan kayu, dan limbah domestic. $^{13}$

Berdasarkan hasil analisis bahwa kandungan logam $\mathrm{Pb}, \mathrm{Zn}$ dan Cu pada sampel ikan bandeng (Chanos chanos Forsk.) yang berasal dari Labbakkang Kabupaten Pangkep tidak melebihi ambang batas yang sudah ditetapkan. Menurut Dirjen POM, standar maksimum kadar logam $\mathrm{Pb}$ dalam makanan adalah 2,0 mg/kg; logam Zn adalah 100,0 mg/kg; dan untuk logam $\mathrm{Cu}$ adalah 20,0 mg/kg. Meskipun demikian, harus diwaspadai karena efek toksisnya tidak langsung terlihat setelah beberapa tahun karena sifatnya yang cenderung terakumulasi pada makhluk hidup. Sifat akumulasi inilah yang menyebabkan efeknya menjadi lebih berbahaya untuk manusia. Bila manusia mengkonsumsi ikan yang tercemar logam terus menerus, akan terjadi akumulasi atau penumpukan logam berat tersebut dalam tubuh. Lama-kelamaan kadar logam berat ini dalam tubuh manusia mencapai tingkat yang menimbulkan keracunan yang dapat membahayakan kesehatan bahkan menimbulkan kematian.

\section{KESIMPULAN}

Kadar rata-rata logam timbal (Pb) dalam sampel ikan bandeng (Chanos chanos Forsk.) yang berasal dari Labbakkang Kabupaten Pangkep adalah sebesar 0,0392 mg/kg. Kadar rata-rata logam tembaga $(\mathrm{Cu})$ dalam sampel ikan bandeng (Chanos chanos Forsk.) yang berasal dari Labbakkang Kabupaten Pangkep adalah sebesar $0,0882 \mathrm{mg} / \mathrm{kg}$. Tidak terdapat 
Analisis kadar timbal $(\mathrm{Pb})$, seng $(\mathrm{Zn})$ dan tembaga $(\mathrm{Cu})$ pada ikan bandeng (Chanos chanos Forsk.) yang berasal dari Labbakkang Kab. Pangkep secara Spektrofotometri Serapan Atom

kandungan logam seng ( $\mathrm{Zn})$ dalam

sampel ikan bandeng (Chanos chanos

Forsk.) yang berasal dari Labbakkang

Kabupaten Pangkep.

\section{DAFTAR PUSTAKA}

1. Heruwati ES. Keamanan Produk Perikanan Sebelum dan Selama Pengolahan, Serta Selama Penyimpanan dan Distribusi. Prosiding Antar Universitas Pangan dan Gizi. Seminar Keamanan dalam Pengolahan dan Penyajian. Yogyakarta: Universitas Gadjah Mada, 1986.

2. Suprapti ML. Teknologi Pangan. Yogyakarta: Penerbit Kanisius, 2002.

3. Cahyono B. Budidaya Ikan di Perairan Umum. Yogyakarta: Kanisus Anggota IKAPI, 2001.

4. Ahmad T, Ratnawati E, Yakub MJR. Budidaya Bandeng Secara Intensif. Penebar Swadaya, 2000.

5. Eridani R. Sedap Sekejap. 10 th ed. Jakarta: Penerbit PT Media Boga Utama, 2000.

6. Sulistia GG. Farmakologi dan Terapi Edisi V. Jakarta: UI Press, 2007.
7. Widowati, Wahyu. Efek Toksik Logam: Pencegahan dan Penanggulangan Pencemaran. Yogyakarta: Penerbit Andi, 2008.

8. Anonim. Direktorat Jenderal Perikanan Budidaya. Jakarta: Budidaya Bandeng, 2010.

9. Arifin, Zainal. Beberapa Unsur Mineral Esensial Mikro Dalam Sistem Biologi dan Metode Analisisnya. Jurnal Litbang Pertanian 2008;(27)3:99-105.

10. Peraturan Pemerintah Republik Indonesia Nomor 82 Tahun 2001 tentang Pengelolaan Kualitas Air dan Pengendalian Pencemaran Air.

11. Surat Keputusan Direktur Jenderal Pengawasan Obat dan Makanan No. 03725/B/SK/89 tentang Batas Maksimum Cemaran Logam dalam Ikan dan Hasil Olahannya.

12. Palar H. Pencemaran Dan Toksikologi Logam Berat. Jakarta : Rineka Cipta Jakarta, 2008.

13. Marganof. Potensi Limbah Udang Sebagai Penyerap Logam Berat $(\mathrm{Pb}, \mathrm{Cd}$ dan $\mathrm{Cu})$ di Perairan (Online).(http://rudyct.topeities.com /pps70271034/marganof.htm.,2003 